\title{
Systematic Identification of Host Immune Key Factors Influencing Viral Infection in PBL of ALV-J Infected SPF Chicken
}

\author{
Manman Dai ${ }^{1,2, *}$, Shibing Li ${ }^{1}$, Keyi Shi ${ }^{1}$, Jiayu Liao ${ }^{1}$, Hui Sun ${ }^{1}$ and Ming Liao ${ }^{1,2, *}$ \\ 1 College of Veterinary Medicine, South China Agricultural University, Guangzhou 510642, China; \\ lishibin10086@163.com (S.L.); huanongshiky@163.com (K.S.); ljy153034045@163.com (J.L.); \\ swhsunhui@163.com (H.S.) \\ 2 National and Regional Joint Engineering Laboratory for Medicament of Zoonosis Prevention and Control, \\ Guangzhou 510642, China \\ * Correspondence: daimanman1229@163.com (M.D.); mliao@scau.edu.cn (M.L.); \\ Tel.: +86-20-8528-0718 (M.D.); +86-8528-0240 (M.L.); Fax: +86-20-8528-0718 (M.D.); +86-8528-5282 (M.L.)
}

Received: 19 December 2019; Accepted: 9 January 2020; Published: 16 January 2020

\begin{abstract}
Although research related to avian leukosis virus subgroup J (ALV-J) has lasted for more than a century, the systematic identification of host immune key factors against ALV-J infection has not been reported. In this study, we establish an infection model in which four-week-old SPF chickens are infected with ALV-J strain CHN06, after which the host immune response is detected. We found that the expression of two antiviral interferon-stimulated genes (ISGs) (Mx1 and IFIT5) were increased in ALV-J infected peripheral blood lymphocytes (PBL). A significant $\mathrm{CD} 8^{+} \mathrm{T}$ cell response induced by ALV-J appeared as early as seven days post-infection (DPI), and humoral immunity starting from 21 DPI differed greatly in the time scale of induction level. Meanwhile, the ALV-J viremia was significantly decreased before antibody production at 14 DPI, and eliminated at 21 DPI under a very low antibody level. The up-regulated CD8 ${ }^{+} \mathrm{T}$ cell in the thymus (14DPI) and PBL (7 DPI and 21 DPI) was detected, indicating that the thymus may provide the output of $\mathrm{CD} 8^{+} \mathrm{T}$ cell to PBL, which was related to virus clearance. Besides, up-regulated chemokine CXCLi1 at 7 DPI in PBL was observed, which may be related to the migration of the $\mathrm{CD} 8^{+} \mathrm{T}$ cell from the thymus to PBL. More importantly, the $\mathrm{CD} 8$ high+ $\mathrm{T}$ cell response of the $\mathrm{CD} 8 \alpha \beta$ phenotype may produce granzyme $\mathrm{K}$, NK lysin, or IFN- $\gamma$ for clearing viruses. These findings provide novel insights and direction for developing effective ALV-J vaccines.
\end{abstract}

Keywords: chicken; ALV-J; CD8 ${ }^{+} \mathrm{T}$ cell response; phenotype; PBL

\section{Introduction}

The avian leukosis virus subgroup J (ALV-J) has caused severe economic losses in the poultry industry worldwide due to its great pathogenicity and transmission ability [1]. Unfortunately, there are still no vaccines or drugs which effectively protect against ALV-J infection. Thus, the big project, ALV eradication, has become a major measure for the prevention and control of ALV-J, which is funds-, manpower-, and technology-dependent. Besides, factors such as the fluctuation of reproductive hormones would also influence the efficiency of eradication via inducing ALV-J viremia disappearance in positively infected chickens [2]. Not surprisingly, ALV eradication is a big challenge, especially in developing countries like China. Therefore, some researchers are still devoted to developing various vaccines, such as subunit vaccines, by using the gp85 protein of ALV-J, multi-epitope subunit vaccine, and chimeric multi-epitope-based DNA vaccine [3-6]. However, none of these vaccines are commercial or applied in chicken farms. In fact, a full understanding of the ALV-induced adaptive immune 
response is the premise to developing effective vaccines. Regretfully, to our knowledge, the systematic identification of host immune key factors against ALV-J infection has not been reported, and still less the immunodominant viral antigen or epitope eliciting the effective immune response.

ALV-J as a kind of notorious retrovirus could cause neoplastic disease, immunosuppression, and other production problems. Historically, ALV studies have mainly focused on the virus itself, including exploring the mechanisms of tumorigenesis, virus isolation, viral replication, and pathogenesis [7-9]. However, ALV-related immunology research is still in its infancy. Despite our knowledge of immunosuppression, immunologic tolerance, antibody response, and interferon-stimulated gene (ISG) expression induced by ALV-J [10-13], there are still major gaps in our understanding of immune responses against ALV-J infection. In a previous study, an infection model was established in which seven- or 11-day-old embryos, and one- or seven-day-old SPF chickens were infected with the virus and used to study the pathogenesis of ALV-J, including tumorigenesis, immunosuppression, and immunologic tolerance [9-11]. In this study, four-week-old, fully developed SPF chickens with immune organs were used to study the host optimal immune response after ALV-J infection. This infectious model was also able to be a reference for studying other virus-induced optimal immune responses.

Previously, we summarized the progress on chicken $\mathrm{T}$ cell immunity to viruses, and found that no ALV-related T cell epitope was functionally identified [14], implying the present scarcity in the study of the ALV-J induced cell immune response. Here, we systematically identified the host immune response in peripheral blood lymphocytes (PBL) of ALV-J infected SPF chickens and elucidated the potential key factors influencing viral infection, especially the phenotype and function of the important $\mathrm{T}$ cell response.

\section{Materials and Methods}

\subsection{Ethics Statement}

All animal research projects were sanctioned by the South China Agriculture University Institutional Animal Care and Use Committee (identification code: 2019076, 10 June 2019). All animal procedures were performed according to the regulations and guidelines established by this committee and international standards for animal welfare.

\subsection{Virus and Experimental Animals}

The ALV J subgroup strain CHN06 was isolated and identified by our laboratory [9]. A total of 28 two-week-old, specific-pathogen-free (SPF) White Leghorn chickens (Guangdong Da Hua Nong Animal Health Products Co., Ltd., Guangdong, China) were randomly assigned to two groups, namely, a CHN06-infected group and control group, each with 14 chickens per group which were reared separately in negative-pressure isolators. After feeding for two weeks, four-week-old SPF chickens were inoculated intraperitoneally at a dose of $0.8 \mathrm{~mL}\left(10^{4} \mathrm{TCID}_{50} / 0.1 \mathrm{~mL}\right)$ of strain CHN06. The control group was injected with $0.8 \mathrm{~mL}$ PBS alone. At 14 and 28 days post-infection (DPI), two infected chickens and three control chickens were humanely sacrificed. At 42 DPI, three chickens per group were humanely euthanized. The spleens and thymus were aseptically collected at each time point, respectively.

\subsection{ALV-J Shedding, ALV-J Viremia, ALV-J Antibody Detection}

To monitor virus shedding, cloacal swabs were collected from chickens from 7 DPI to 63 DPI, and preserved in the diluent of ALV-P27 Ag Test Kit (IDEXX, Inc., Westbrook, MA, USA). Levels of p27 expression in cloacal swabs were examined following the manufacturer's instructions. To monitor viremia, plasma samples were aseptically collected from chickens from 7 DPI to 63 DPI and centrifuged at $4{ }^{\circ} \mathrm{C}$ at $2000 \mathrm{rpm}$ for $12 \mathrm{~min}$ to isolate leukocytes. These were then inoculated into DF1 cells at $37^{\circ} \mathrm{C}$ for seven days to check for the presence of the virus by using an ALV-P27 Ag Test Kit (IDEXX, Inc.). 
The relative antigen titer level was determined by calculating the S/P ratio, and the cloacal swabs and plasma samples with a $\mathrm{S} / \mathrm{P}$ ratio higher than 0.2 were considered virus-positive.

To monitor the anti-ALV-J antibody titers, the serum samples were collected from chickens from 7 DPI to 63 DPI and examined for the level of ALV-J antibody using a commercial ALV-J antibody test kit (IDEXX, Inc.) according to the manufacturer's protocol. The relative antibody level in the serum was determined by calculating the $\mathrm{S} / \mathrm{P}$ ratio, and a ratio higher than 0.6 was considered ALV-J antibody-positive.

\subsection{Lymphocyte Isolation}

Five days before infection (DBI) and each week after infection, heparinized blood samples from individual chickens were collected to isolate peripheral blood lymphocytes (PBL) of chicken lymphocyte separation medium according to the manufacturer's instructions (Solarbio, Beijing, China). Briefly, the heparinized blood was slowly added to the top of the lymphocyte separation medium and then centrifuged with $400 \mathrm{~g}$ for $15 \mathrm{~min}$ when the falling acceleration was set to 1 . After centrifugation, three layers appeared, and the interlayer was lymphocyte. The interlayer was transferred to a new tube and washed with cleaning fluid. After centrifugation with $1700 \mathrm{rpm}$ for $5 \mathrm{~min}$, red-blood-cell lysis buffer (Haoyang, Tianjin, China) was used to remove the mixed blood cells. After that, the PBL was prepared.

Single-cell suspensions derived from the spleen and thymus were obtained in RPMI 1640 medium (Gibco, CA, USA) of the tissue mononuclear cell kit, according to the manufacturer's instructions (Haoyang, Tianjin, China). Briefly, tissue cell suspensions were obtained by mechanical disruption. The lymphocyte was isolated with the tissue separation medium in the kit, as described above. Cell viability and counting was performed using Trypan Blue and a Neubauer hemocytometer (Sigma-Aldrich, St. Louis, MO USA). The chicken PBL and tissue single-cell suspensions were frozen in liquid nitrogen for later study.

\subsection{Flow Cytometry}

$3 \times 10^{5}$ cells of PBL or tissue single-cell suspensions were simultaneously incubated with APC-conjugated mouse anti-chicken $\mathrm{CD}^{+}$, FITC-conjugated mouse anti-chicken $\mathrm{CD}^{+}$, and PE-conjugated mouse anti-chicken $\mathrm{CD} 8 \alpha^{+}$monoclonal antibodies (SouthernBiotech, Birmingham, USA) in the dark at $4{ }^{\circ} \mathrm{C}$ for $30 \mathrm{~min}$. After three washes with PBS, the labeled cells were analyzed by flow cytometer (CytoFLEX, Beckman Coulter, Brea, CA, USA) within $12 \mathrm{~h}$. The data were analyzed by the software of FlowJo V10 (TreestarInc, Ashland, OR, USA). For the phenotype identification of the $\mathrm{CD} 8^{+} \mathrm{T}$ cell, FITC-conjugated mouse anti-chicken $\mathrm{CD} 8 \beta^{+}$and APC-conjugated mouse anti-chicken $\mathrm{CD}^{+}$monoclonal antibodies (SouthernBiotech, Birmingham, USA) were also used.

\subsection{Expression Analysis of Immune-Related Gene by qRT-PCR}

Expressions of the immune-related gene were analyzed by a quantitative real-time polymerase chain reaction (qRT-PCR). Total RNA was extracted from $4 \times 10^{6}$ live cells of post-thawed PBL using the RNAfast200 kit (Fastagen, Shanghai, China), followed by cDNA synthesis of mRNA with the RevertAid First strand cDNA synthesis kit (Thermo-Fisher Scientific, Shanghai, China) according to the manufacturer's instructions. qRT-PCR was performed on an ABI7500 Real-Time PCR system (Applied Biosystems, USA) using iTaqTM Universal SYBR R Green Supermix Kit reagents (Biorad, CA, USA) according to the manufacturer's specifications. Primers used for qRT-PCR were listed in Table 1. Data analyses were performed using the $2^{-\Delta \Delta C t}$ method [15]. 
Table 1. Primers used for the quantitative real-time polymerase chain reaction (qRT-PCR).

\begin{tabular}{|c|c|c|c|c|}
\hline Target & Primer & Sequence $\left(5^{\prime}-3^{\prime}\right)$ & $\begin{array}{c}\text { Gen Bank } \\
\text { Accession No. }\end{array}$ & Reference \\
\hline \multirow{2}{*}{ GAPDH } & Forward & GAACATCATCCCAGCGTCCA & \multirow{2}{*}{ NM_204305.1 } & \multirow{2}{*}{ [16] } \\
\hline & Reverse & CGGCAGGTCAGGTCAACAAC & & \\
\hline \multirow{2}{*}{ IFN- $\alpha$} & Forward & GACAGCCAACGCCAAAGC & \multirow{2}{*}{ GU119896.1 } & \multirow{2}{*}{ [16] } \\
\hline & Reverse & GTCGCTGCTGTCCAAGCATT & & \\
\hline \multirow{2}{*}{ IFN- $\beta$} & Forward & GCCCACACACTCCAAAACACTG & \multirow{2}{*}{ NM_001024836.1 } & \multirow{2}{*}{ [16] } \\
\hline & Reverse & TTGATGCTGAGGTGAGCGTTG & & \\
\hline \multirow{2}{*}{ IL-1 $\beta$} & Forward & GGTCAACATCGCCACCTACA & \multirow{2}{*}{ NM_204524.1 } & \multirow{2}{*}{ [16] } \\
\hline & Reverse & CATACGAGATGGAAACCAGCAA & & \\
\hline \multirow{2}{*}{ TNF- $\alpha$} & Forward & GCTGTTCTATGACCGCCCAGTT & \multirow{2}{*}{ NM_204267.1 } & \multirow{2}{*}{ [16] } \\
\hline & Reverse & AACAACCAGCTATGCACCCCA & & \\
\hline \multirow{2}{*}{ IL-2 } & Forward & GCTAATGACTACAGCTTATGGAGCA & \multirow{2}{*}{ AF000631.1 } & \multirow{2}{*}{ [16] } \\
\hline & Reverse & TGGGTCTCAGTTGGTGTGTAGAG & & \\
\hline \multirow{2}{*}{ IL-6 } & Forward & ААATCССТССТСGССАATCT & \multirow{2}{*}{ AJ309540.1 } & \multirow{2}{*}{ [16] } \\
\hline & Reverse & CCСTCACGGTCTTCTCCATAAA & & \\
\hline \multirow{2}{*}{ IL-10 } & Forward & AGCAGATCAAGGAGACGTTC & \multirow{2}{*}{ NM_001004414.2 } & \multirow{2}{*}{ [16] } \\
\hline & Reverse & ATCAGCAGGTACTCCTCGAT & & \\
\hline \multirow{2}{*}{ TLR3 } & Forward & ACAATGGCAGATTGTAGTCACCT & \multirow{2}{*}{ NM_001011691.3 } & \multirow{2}{*}{ [16] } \\
\hline & Reverse & GCACAATCCTGGTTTCAGTTTAG & & \\
\hline TLR7 & Forward & TCTGGACTTCTCTAACAACA & NM_001011688.2 & [16] \\
\hline & Reverse & ААТСТСАТТСТСАТТСАТСАТСА & & \\
\hline MHC-I & Forward & AAGAAGGGGAAGGGCTACAA & NM_001031338.1 & [16] \\
\hline & Reverse & AAGCAGTGCAGGCAAAGAAT & & \\
\hline MHC-II & Forward & CTCGAGGTCATGATCAGCAA & DQ008588.2 & [16] \\
\hline & Reverse & TGTAAACGTCTCCCCTTTGG & & \\
\hline IFN- $\gamma$ & Forward & ССТССААСАССТСТТСААСАТG & X92479 & [17] \\
\hline & Reverse & TGGCGTGCGGTCAAT & & \\
\hline IL-4 & Forward & TCGAGGAGTGACGGGTG & AJ621249.1 & [17] \\
\hline & Reverse & ACTATCCGGATGCTCTCCATC & & \\
\hline IL -5 & Forward & GGAACGGCACTGTTGAAAAATAA & AJ621252.1 & [18] \\
\hline & Reverse & TTCTCССТСТССТGTCAGTTGTG & & \\
\hline IL-13 & Forward & CTGCCCTTGCTCTCCTCTGT & AJ621250.1 & [18] \\
\hline & Reverse & CCTGCACTCCTCTGTTGAGCTT & & \\
\hline Granzyme A & Forward & ACTCATGTCGAGGGGATTCA & NM_204457.1 & [19] \\
\hline & Reverse & TGTAGACACCAGGACCACCA & & \\
\hline Granzyme K & Forward & CGGGAAGCAACTGTTGAAAT & XM_423832 & [19] \\
\hline & Reverse & GAGTCTCCCTTGCAAGCATC & & \\
\hline MDA5 & Forward & GGACGACCACGATCTCTGTGT & NM 001193638.1 & [20] \\
\hline & Reverse & CACCTGTCTGGTCTGCATGTTATC & & \\
\hline
\end{tabular}


Table 1. Cont.

\begin{tabular}{|c|c|c|c|c|}
\hline Target & Primer & Sequence $\left(5^{\prime}-3^{\prime}\right)$ & $\begin{array}{c}\text { Gen Bank } \\
\text { Accession No. }\end{array}$ & Reference \\
\hline \multirow{2}{*}{ CXCLi1 } & Forward & AACTCCGATGCCAGTG & \multirow{2}{*}{ NM_205018.1 } & \multirow{2}{*}[21]{} \\
\hline & Reverse & TTGGTGTCTGCCTTGT & & \\
\hline \multirow{2}{*}{ CXCLi2 } & Forward & CATCATGAAGCATTCCATCT & \multirow{2}{*}{ NM_205498.1 } & \multirow{2}{*}[21]{} \\
\hline & Reverse & CTTCCAAGGGATCTTCATTT & & \\
\hline \multirow{2}{*}{ TGF- $\beta 3$} & Forward & TCTTTACATTGACTTCCGAC & \multirow{2}{*}{ NM_205454.1 } & \multirow{2}{*}{ [21] } \\
\hline & Reverse & TCСТСССАACATAGTACAAG & & \\
\hline \multirow{2}{*}{ MX1 } & Forward & AAGCCTGAGCATGAGCAGAA & \multirow{2}{*}{ NM_204609.1 } & \multirow{2}{*}{ [22] } \\
\hline & Reverse & TCTCAGGCTGTCAACAAGATCAA & & \\
\hline \multirow{2}{*}{ OASL } & Forward & AGATGTTGAAGCCGAAGTACCC & \multirow{2}{*}{ NM_205041.1 } & \multirow{2}{*}{ [22] } \\
\hline & Reverse & CTGAAGTCCTCCCTGCCTGT & & \\
\hline \multirow{2}{*}{ ISG12-2 } & Forward & TCAATGGGTGGCAAAGGAG & \multirow{2}{*}{ NM_001001296.5 } & \multirow{2}{*}{ [22] } \\
\hline & Reverse & TACAGGGAGAGCAAAGAAGAGAAGA & & \\
\hline \multirow{2}{*}{ IFIT5 } & Forward & CAGAATTTAATGCCGGCTATGC & \multirow{2}{*}{ XM_421662.4 } & \multirow{2}{*}{ [22] } \\
\hline & Reverse & TGCAAGTAAAGCCAAAAGATAAGTGT & & \\
\hline \multirow{2}{*}{ USP18 } & Forward & CAACGTGGGAAGAGGAGAAA & \multirow{2}{*}{ XM_416398.3 } & \multirow{2}{*}{ [22] } \\
\hline & Reverse & ACTTCATGAGCGGAGAAGGA & & \\
\hline \multirow{2}{*}{ IRF3/7 } & Forward & ACTGACCAGCCCAGGAACTCT & \multirow{2}{*}{ NM_205372.1 } & \multirow{2}{*}{ [22] } \\
\hline & Reverse & AAGGCTTTCCСAACСАCAAA & & \\
\hline \multirow{2}{*}{ SST } & Forward & GGTCCACGGTTATGGTGAAAG & \multirow{2}{*}{ NM_205336.1 } & \multirow{2}{*}{ [22] } \\
\hline & Reverse & GGTCAGAAATCACAACTCAAGCA & & \\
\hline \multirow{2}{*}{ KHSRP } & Forward & CAGCGGGGAAATGATTAAGAAG & NM 204277.1 & [22] \\
\hline & Reverse & TTTGTGTGTGGGGATGGAGA & & \\
\hline Perforin & Forward & ATGGCGCAGGTGACAGTGA & XM 425355 & [23] \\
\hline & Reverse & TGGCCTGCACCGGTAATTC & & \\
\hline PARP & Forward & ATTGTGGAGGAGCTGGGAGGAA & NM 205263 & [23] \\
\hline & Reverse & AGGCTTGCTGCACTTCCCATC & & \\
\hline HMG-2 & Forward & AGAGCACAAGAAGAAGCAC & M80574 & [23] \\
\hline & Reverse & GTCTTTTAGGAGCGTTGGGGTC & & \\
\hline NK lysin & Forward & GATGGTTCAGCTGCGTGGGATGC & DQ186291 & [23] \\
\hline & Reverse & CTGCCGGAGCTTCTTCAACA & & \\
\hline
\end{tabular}

\subsection{Statistical Analyses}

Statistical comparisons were made by GraphPad Prism 5 (GraphPad Software Inc., San Diego, CA, USA). The results were presented as mean \pm SEM. ${ }^{*} p<0.05,{ }^{* *} p<0.01,{ }^{* *} p<0.001$, ns indicates not significant.

\section{Results}

\subsection{Dynamic Detection of ALV-J Shedding, ALV-J Viremia, and ALV-J Antibody}

Four-week-old SPF chickens were infected with ALV-J for 63 days, and the ALV-J shedding, ALV-J viremia, and ALV-J antibody were continuously monitored every seven days. In the control group, 
the ALV-J shedding, ALV-J viremia, and ALV-J antibody are all negative at all time points. In the ALV-J infected group, ALV-J shedding detection by the cloacal swab-specific p27 antigen is negative with a $\mathrm{S} / \mathrm{P}$ ratio below 0.2 at all the time points (Figure 1A). Besides this, ALV-J viremia detection by plasma sample-specific p27 antigen is $100 \%$ positive at $7 \mathrm{DPI}, 60 \%$ positive at $14 \mathrm{DPI}$, and $100 \%$ negative at later time points. Moreover, the viral load of plasma samples is much lower at 14 DPI than 7 DPI $(p<0.05$, Figure 1B). Additionally, the ALV-J antibody is $100 \%$ negative at 7 DPI and 14 DPI, $20 \%$ positive at $21 \mathrm{DPI}, 60 \%$ positive from $28 \mathrm{DPI}$ to $56 \mathrm{DPI}$, and $80 \%$ positive at $63 \mathrm{DPI}$. Also, the average ALV-J antibody level is slightly growing at a gradual rate (Figure 1C). Intriguingly, ALV-J infection is significantly suppressed at 14 DPI without antibody production (Figure 1B,C), which indicates that other host immune factors play a crucial role against ALV-J infection. More importantly, we found that ALV-J infection had been eliminated in four infected chickens without antibody production (Table S1). As shown in Figure 1D, the viremia in infected chicken number 12 disappeared at 14 DPI without antibody production in the whole monitoring process, which implies that the antibody-namely, humoral immunity—may not be the key or necessary factor to defending against ALV-J infection.

A

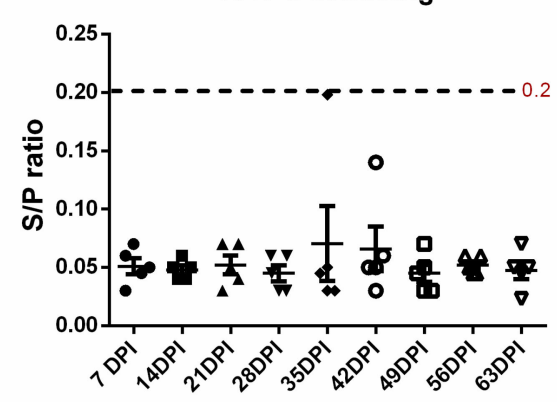

C

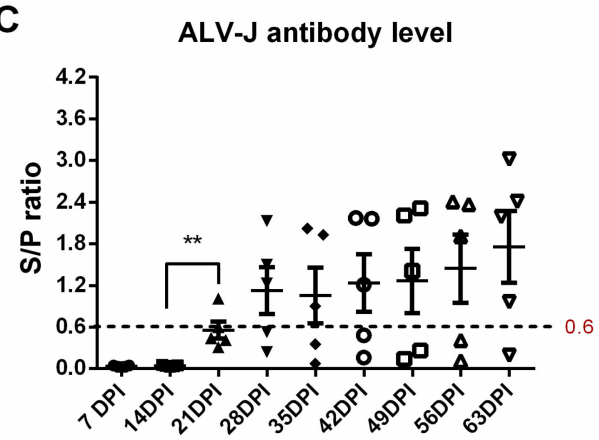

B

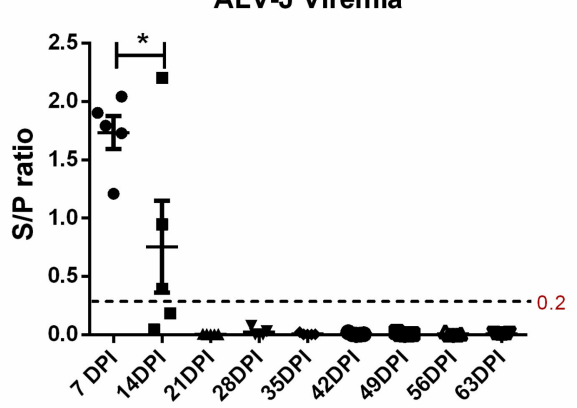

D

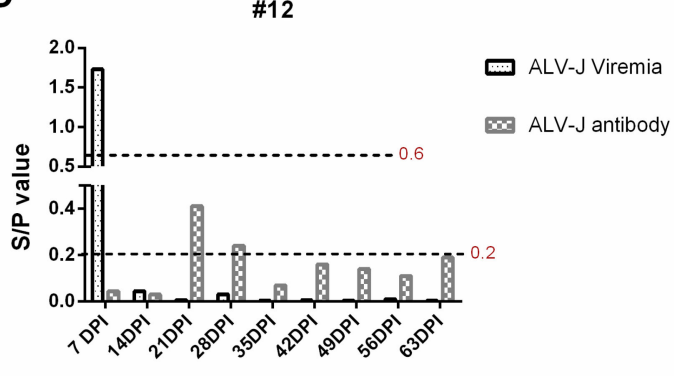

Figure 1. Dynamic detection of the avian leukosis virus subgroup J (ALV-J) shedding, ALV-J viremia, and ALV-J antibody. Five chickens were randomly selected for sampling every seven days post-infection (DPI). (A) ALV-J shedding was monitored via detecting the p27 expression levels in cloacal swabs. $\mathrm{S} / \mathrm{P}$ value below 0.2 (red) indicated negative ALV-J shedding. (B) ALV-J viremia was monitored via virus isolation with the routine method. An S/P value above 0.2 (red) indicated positive ALV-J viremia. (C) The ALV-J antibody level in the serum was monitored using the commercial ALV-J antibody test kit. An S/P value above 0.6 (red) was considered ALV-J antibody positive. (D) ALV-J viremia and antibody level of chicken number 12 were analyzed from 7 DPI to 63 DPI. The paired $t$-test was used for statistical comparison. ${ }^{*} p<0.05,{ }^{* *} p<0.01$.

\subsection{Dynamic Detection of T Lymphocyte Percentage}

In order to explore the role of cellular immunity against ALV-J infection, the T lymphocyte percentage was detected in PBL and immune organs. As shown in Figure 2, in PBL, the percentage of $\mathrm{CD}^{+} \mathrm{T}$ lymphocytes in the infection group obviously increased at 7 DPI $(p<0.05)$ and 21 DPI $(p<0.01)$ compared with the control group. On the contrary, there is no significant difference about the percentage of $\mathrm{CD}^{+} \mathrm{T}$ cells and $\mathrm{CD} 4^{+} \mathrm{CD} 8^{+}$double-positive $\mathrm{T}$ cells in PBL between the infection 
group and control group. The ratios of $\mathrm{CD} 4^{+} / \mathrm{CD} 8^{+}$in PBL of the infected group are markedly lower than the control group at $21 \mathrm{DPI}$. Similarly, in the thymus, the percentage of $\mathrm{CD} 8^{+} \mathrm{T}$ lymphocytes and the ratios of $\mathrm{CD}^{+} / \mathrm{CD}^{+}$in the infection group is significantly up- and down-regulated, respectively, at 14 DPI $(p<0.01$ and $p<0.05)$ compared with the control group (Figure S1A, Figure 3$)$. In the spleen, the percentage of $\mathrm{CD} 4^{+} \mathrm{CD} 8^{+}$double-positive T cells in the infection group declined at $42 \mathrm{DPI}(p<0.05)$ compared with the control group, but there is no obvious difference at the other test index (Figure S1B, Figure 4). The fully-developed naïve $\mathrm{T}$ cell in the thymus could be located in the peripheral lymphoid organ via blood circulation [24]. In this study, we detected the up-regulated $\mathrm{CD} 8^{+} \mathrm{T}$ cell in the thymus (14 DPI) and PBL (7 DPI and 21 DPI), indicating that the thymus may provide the output of the CD8 ${ }^{+}$ $\mathrm{T}$ cell to PBL, which was related to virus clearance.
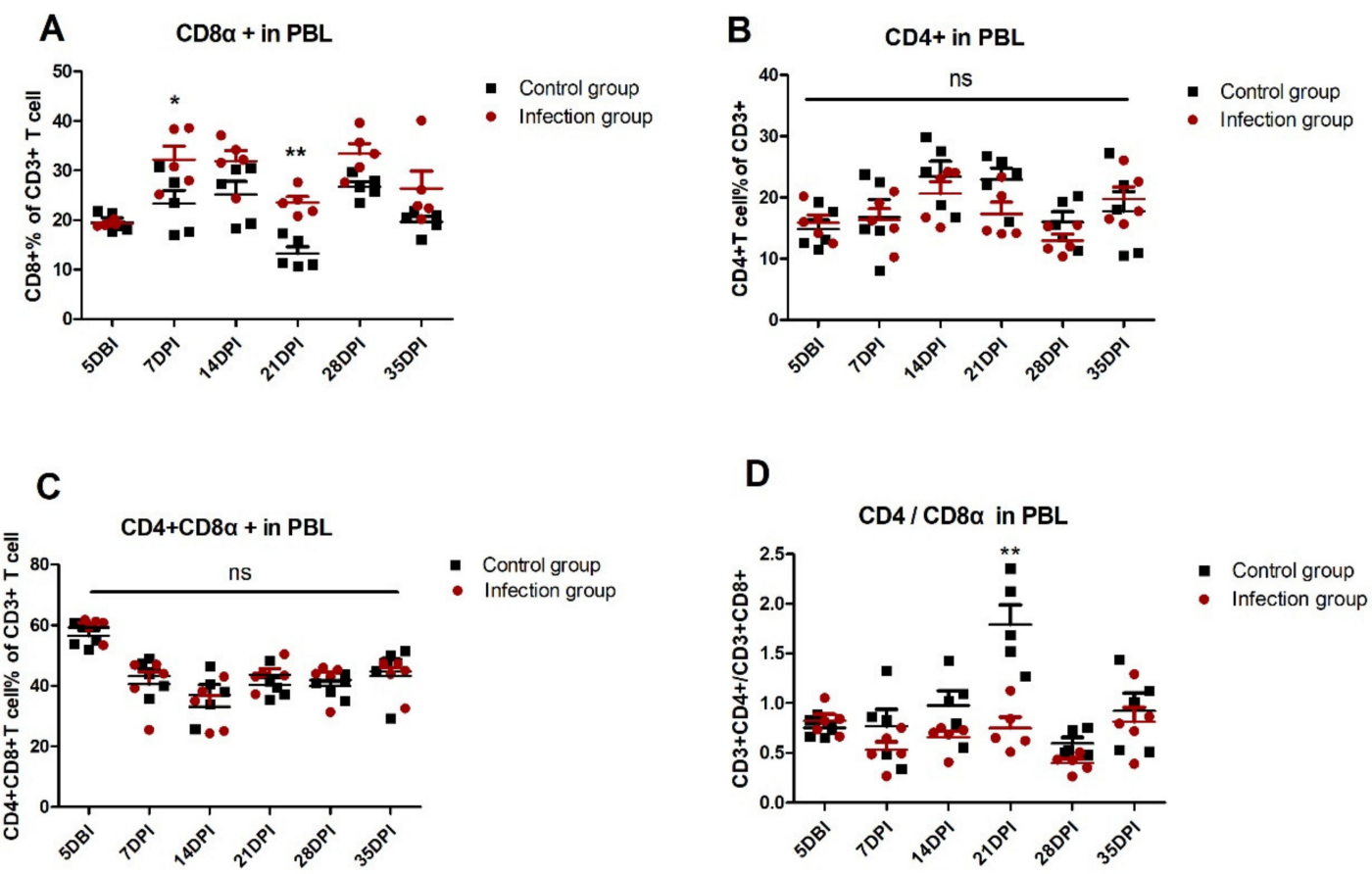

Figure 2. Dynamic detection of T lymphocyte percentage in peripheral blood lymphocytes (PBL). Five days before infection (DBI) and each week after infection, PBL derived from five chickens of infected and control groups were isolated to detect the $\mathrm{T}$ lymphocyte percentage, including the percentage of (A) the $\mathrm{CD}^{+} \mathrm{CD}^{+} \mathrm{T}$ cell, (B) $\mathrm{CD}^{+} \mathrm{CD}^{+} \mathrm{T}$ cell, and (C) $\mathrm{CD}^{+} \mathrm{CD}^{+} \mathrm{CD}^{+}$. (D) The ratio of $\mathrm{CD}^{+} \mathrm{CD}^{+} / \mathrm{CD}^{+} \mathrm{CD}^{+}$was detected. Each sample collected $1 \times 10^{5}$ cells for flow cytometric analysis. The two-way ANOVA was used for statistical comparison. ns $p>0.05,{ }^{*} p<0.05,{ }^{* *} p<0.01$. 
CD8 $\alpha+$ in thymus

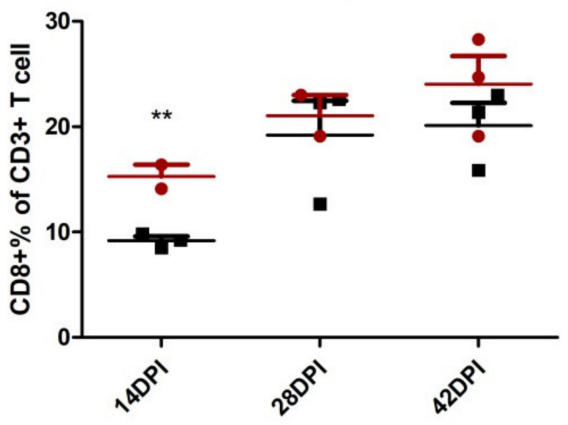

CD4+CD8 $\alpha+$ in thymus

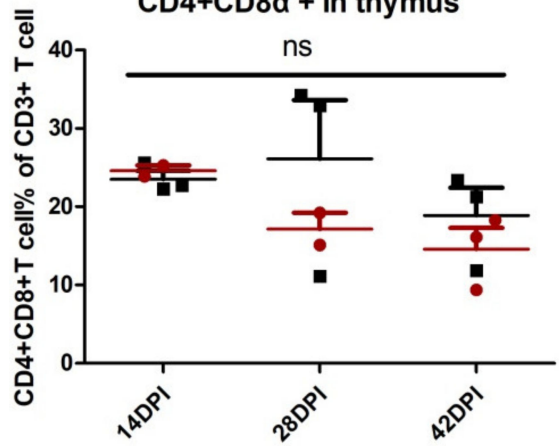

CD4+ in thymus

- Control group

Infection group

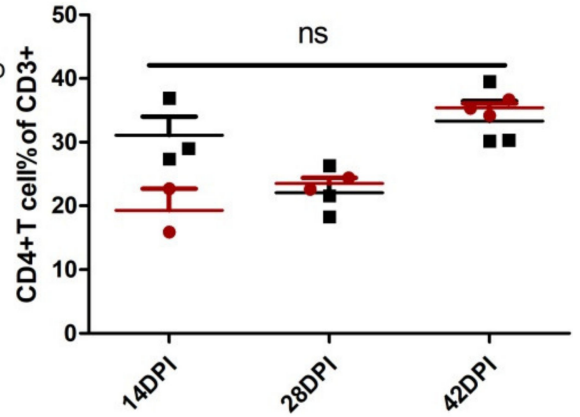

CD4/ CD8 $\alpha$ in thymus

- Control group

- Infection group

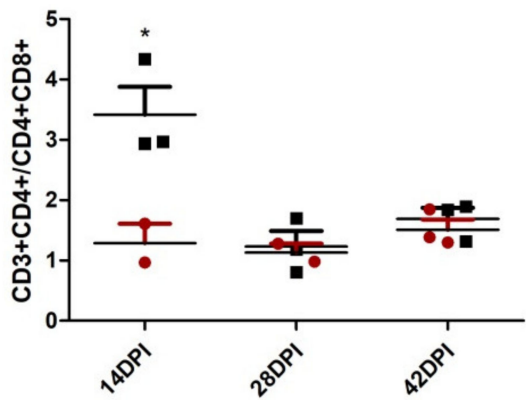

Figure 3. Analysis of T lymphocyte percentage in the thymus. Thymus single-cell suspensions derived from chickens of infected and control groups were isolated to detect the T lymphocyte percentage. Every dot stands for one chicken. The unpaired t-test was used for statistical comparison. ns $p>0.05$, * $p<0.05,{ }^{* *} p<0.01$. Each sample collected $2 \times 10^{5}$ cells for flow cytometric analysis.

CD8 $\alpha+$ in spleen
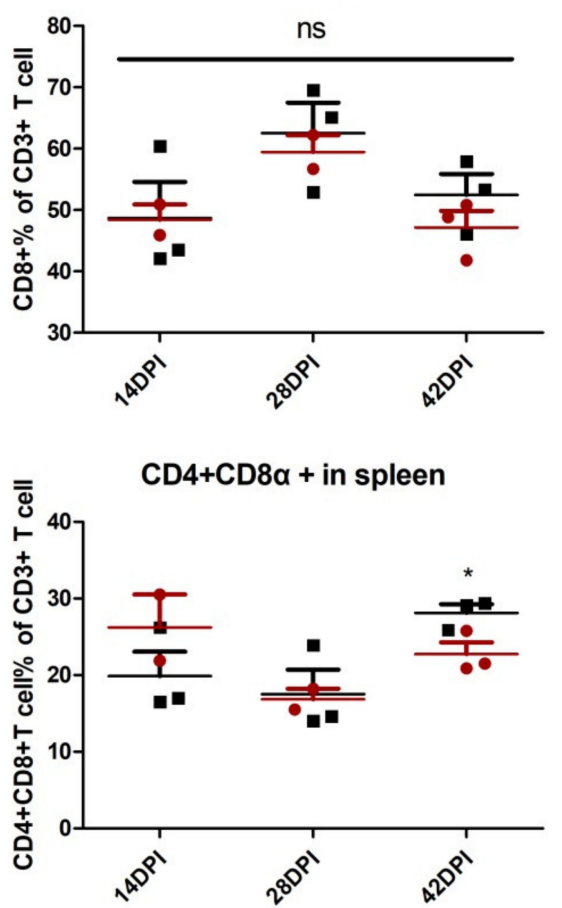

CD4+ in spleen

- Control group

- Infection group

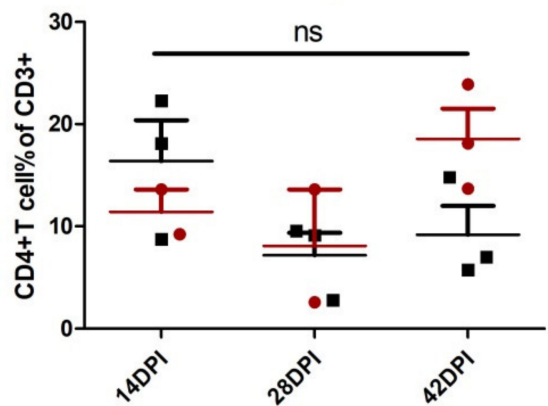

CD4/ CD8 $\alpha$ in spleen

- Control group

- Infection group

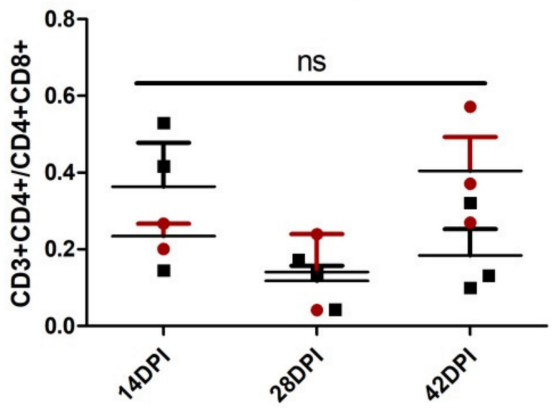

Figure 4. Analysis of T lymphocyte percentage in spleen. Spleen single-cell suspensions derived from chickens of infected and control groups were isolated to detect the Tlymphocyte percentage. Every dot stands for one chicken. The unpaired t-test was used for statistical comparison. ns $p>0.05,{ }^{*} p<0.05$. Each sample collected $2 \times 10^{5}$ cells for flow cytometric analysis. 


\subsection{Kinetic Detection of Immune-related Genes in PBL}

The kinetic expressions of immune-related genes at various time points were detected in PBL after ALV-J infection (Figure 5). Specifically, the transcriptional expression level of cytotoxicity genes, including granzyme K at 14 DPI and 21 DPI, interferon- $\gamma$ (IFN- $\gamma$ ) at 14 DPI, and NK lysin at 28 DPI, and T helper (Th) 2 cytokines, including interleukin-13 (IL-13) at 7 DPI and IL-4 at 28 DPI, and ISG genes, including interferon-induced proteins with tetratricopeptide repeats (IFIT) 5 at 7 DPI and 28 DPI, myxovirus resistance 1 (MX1) at 21 DPI, inflammatory cytokines IL-6 at 14 DPI, and chemokines CXCLi1 at 7 DPI were significantly upregulated $(p<0.05)$ after ALV-J infection.
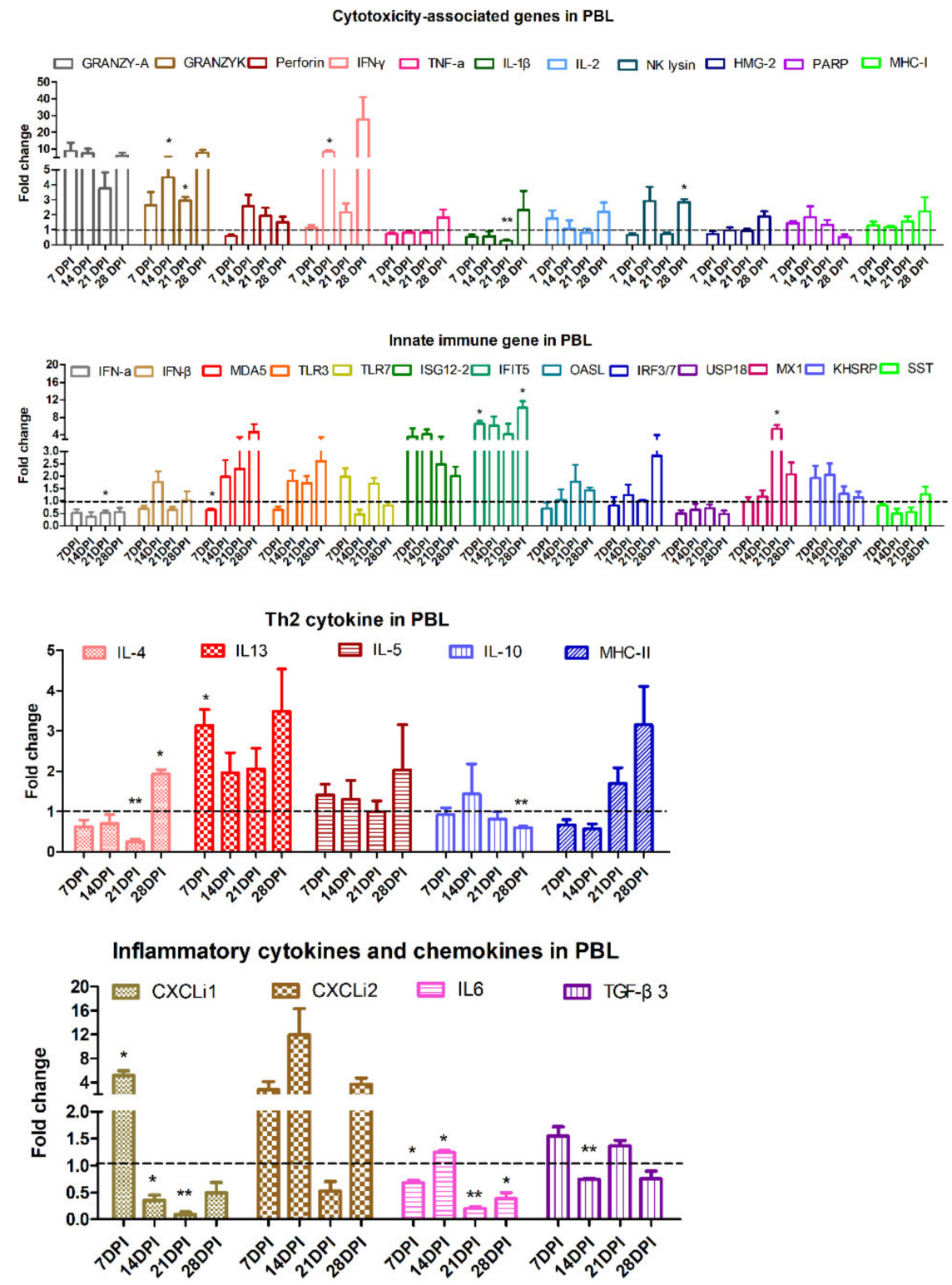

Figure 5. Analysis expression of immune-related genes in PBL by qRT-PCR. Expressions of immune-related genes in PBL were detected by qRT-PCR. The total RNA of PBL was extracted from three chickens of the infected and control groups, respectively. The data was collected from three biological samples in each group, each sample performed in triplicate. The results were presented as means \pm SEM and the paired $t$-test was used for statistical comparison. ns $p>0.05,{ }^{*} p<0.05,{ }^{* *} p<0.01$. 


\section{4. $C D 8^{+} T$ Cell Phenotype Identification}

As described above, the increased percentage of $\mathrm{CD} 8^{+} \mathrm{T}$ lymphocytes in the PBL of the infection group was detected. More interestingly, we found that, compared with uninfected chicken, a CD8 hight population had appeared in the ALV-J infected chicken from 21 DPI, which then formed three stable populations of $\mathrm{CD} 8^{+} \mathrm{T}$ lymphocytes in infected chickens, including CD8 ${ }^{\text {high }+}, \mathrm{CD} 8{ }^{\text {medium}+}$, and $\mathrm{CD} 4^{+} \mathrm{CD} 8$ low+ (Figure 6). Besides, the $\mathrm{CD} 8^{+} \mathrm{T}$ lymphocyte included two phenotypes, $\mathrm{CD} 8 \alpha \alpha$ and $\mathrm{CD} 8 \alpha \beta$, and $\mathrm{CD} 8 \alpha \beta$ was expressed on normal cytotoxic T cells [25]. Thus, we further investigated the phenotype of $\mathrm{CD}^{+} \mathrm{T}$ cells in ALV-J infected chicken number 12 via three combinations of antibody staining. The results showed that almost all of the $\mathrm{CD} 44^{+} \mathrm{CD} 88^{\text {low }}+$ population were of the $\mathrm{CD} 4^{+} \mathrm{CD} 8 \alpha \alpha$ phenotype (Figure 7B). Conversely, the majority of the CD8 hight and CD8 ${ }^{\text {medium+ }}{ }^{+}$population was of the $\mathrm{CD} 8 \alpha \beta$ phenotype (Figure $7 \mathrm{~B}, \mathrm{C}$ ). The contour plot analysis of the CD8 $8^{+} \mathrm{T}$ cell phenotype in the PBL of control chicken number 34 and ALV-J infected chicken number 12 further confirmed the above results (Figure 8). Accordingly, these results implied that the CD8 ${ }^{\text {high+ }}$ population with the CD8 $\alpha \beta$ phenotype seemed to play a vital role in virus clearance.

A
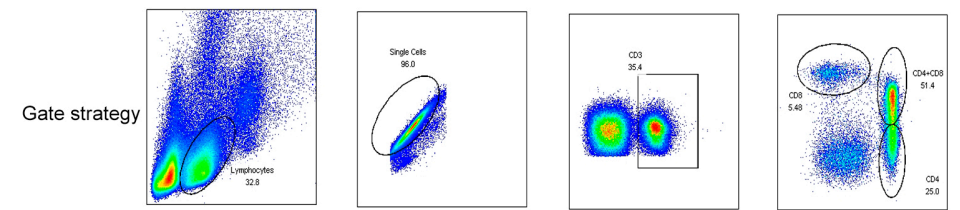

21DPI $28 \mathrm{DPI}$

B
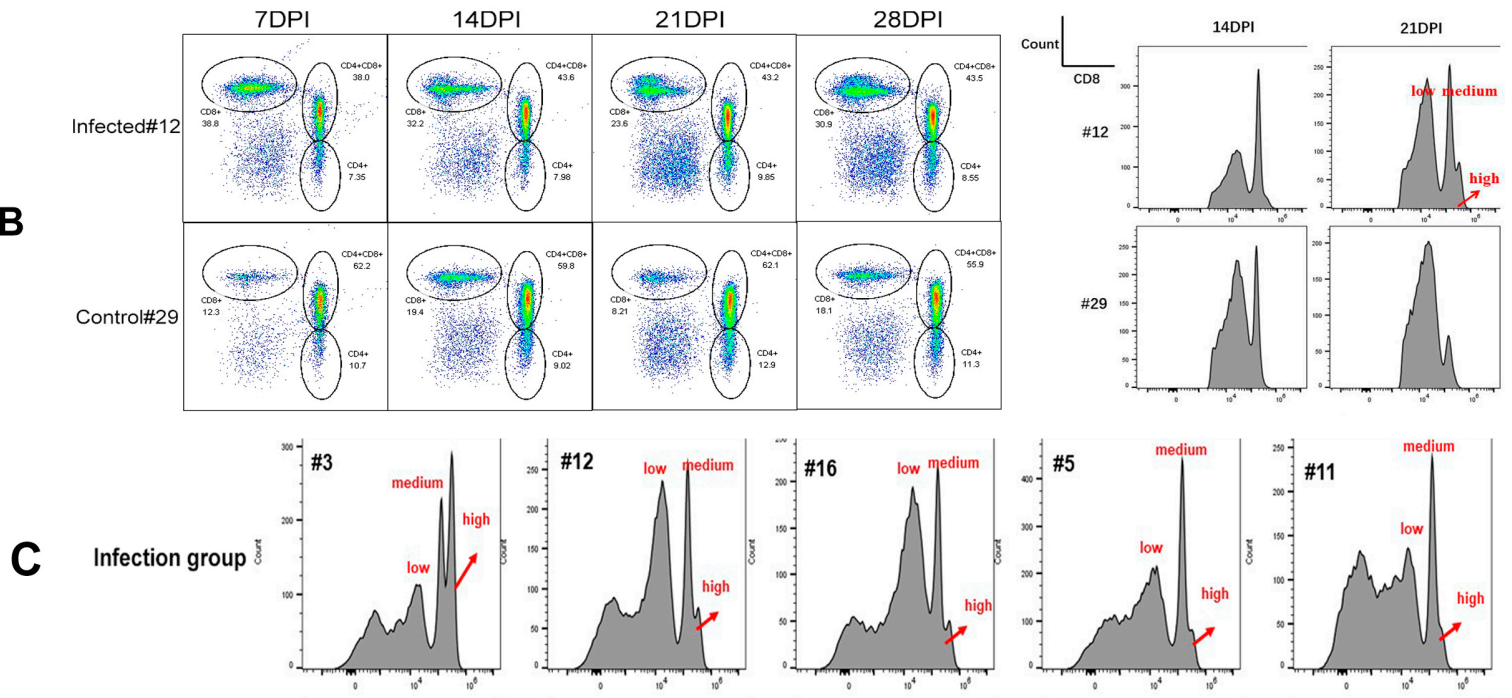

D Control group
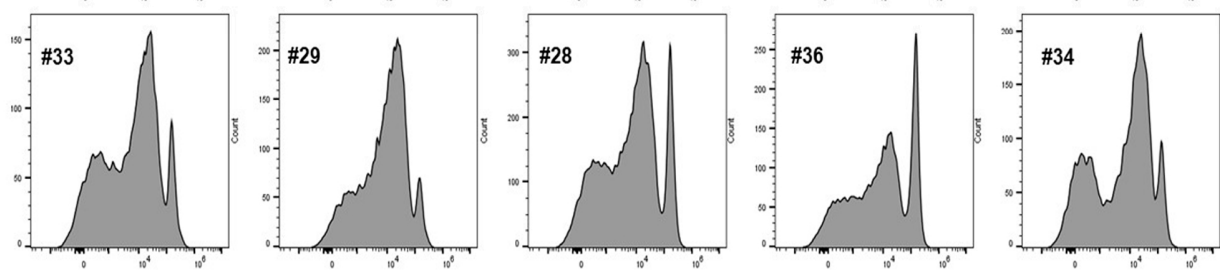

Figure 6. $\mathrm{T}$ cell phenotype analysis. (A) Gating of $\mathrm{CD} 8 \alpha^{+}, \mathrm{CD} 4^{+}$, and $\mathrm{CD} 4^{+} \mathrm{CD} 8 \alpha^{+} \mathrm{T}$ cells with the $\mathrm{CD}^{+}(\mathrm{APC}), \mathrm{CD}^{+}(\mathrm{FITC})$, and $\mathrm{CD} 8 \alpha^{+}(\mathrm{PE})$ antibodies. (B) Analysis of the percentage and phenotype of $\mathrm{T}$ cells in PBL of ALV-J infected chicken number 12 and control chicken number 29 at various time points. Histogram of the $\mathrm{CD}^{+} \mathrm{CD} 8 \alpha^{+} \mathrm{T}$ cells in PBL of (C) ALV-J infected group and (D) control group at 21 DPI. Each sample collected $1 \times 10^{5}$ cells for flow cytometric analysis. 

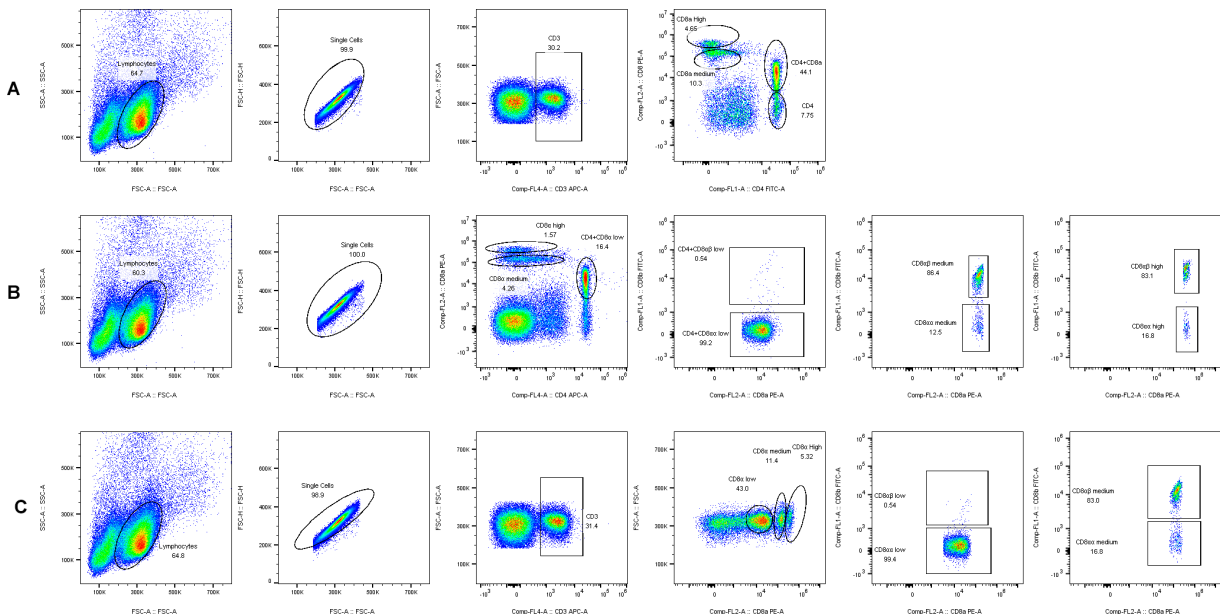
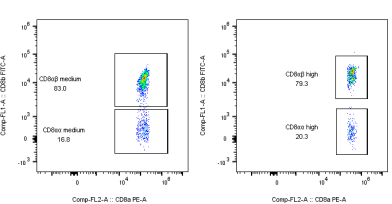

Figure 7. $\mathrm{CD}^{+} \mathrm{T}$ cell phenotype identification in PBL of ALV-J infected chicken number 12. (A) Gating strategy for analysis of $\mathrm{CD} 8^{\text {high }} \alpha^{+}, \mathrm{CD} 8^{\text {medium }} \alpha^{+}, \mathrm{CD} 4^{+}$, and $\mathrm{CD} 4^{+} \mathrm{CD} 8^{\text {low }} \alpha^{+} \mathrm{T}$ cells with the $\mathrm{CD}^{+}(\mathrm{APC}), \mathrm{CD}^{+}(\mathrm{FITC})$, and $\mathrm{CD} 8 \alpha^{+}(\mathrm{PE})$ antibodies. (B) Gating strategy for analysis of $\mathrm{CD} 8^{+}$ $\alpha \alpha$ and $\mathrm{CD}^{+} \alpha \beta$ phenotype in three $\mathrm{CD} 8^{+}$populations with the $\mathrm{CD} 4^{+}$(APC), CD8 $\beta^{+}$(FITC), and $\mathrm{CD} 8 \alpha^{+}$(PE) antibodies. (C) Gating strategy for analysis of $\mathrm{CD}^{+} \alpha \alpha$ and $\mathrm{CD} 8^{+} \alpha \beta$ phenotype in three $\mathrm{CD}^{+}$populations with the $\mathrm{CD}^{+}$(APC), $\mathrm{CD} 8 \beta^{+}$(FITC), and $\mathrm{CD} 8 \alpha^{+}$(PE) antibodies. Each dot indicated each collected cell. And the circle or fame indicated the gated target cell population labelled by various antibodies. Each sample collected $1 \times 10^{5}$ cells for flow cytometric analysis.
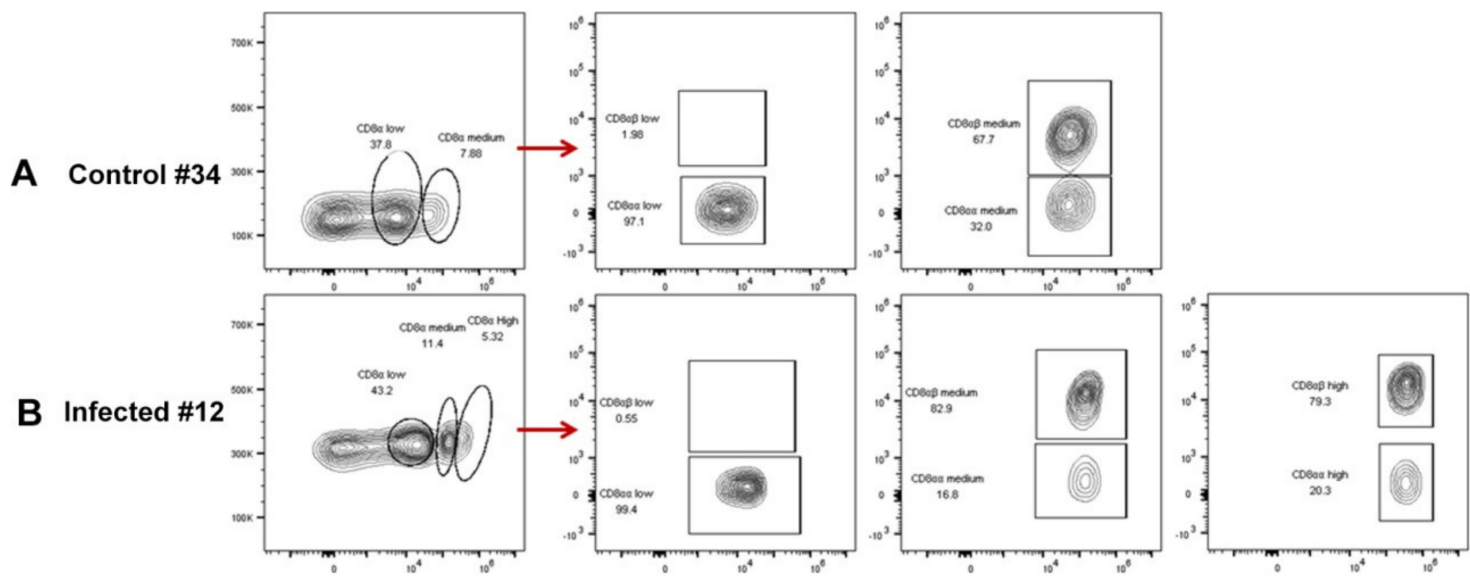

Figure 8. $\mathrm{CD}^{+} \mathrm{T}$ cell phenotype analysis. Contour plot of $\mathrm{CD}^{+} \alpha \alpha$ and $\mathrm{CD} 8^{+} \alpha \beta \mathrm{T}$ cells in PBL of (A) control chicken number 34 and (B) ALV-J infected chicken number 12 with the CD3 ${ }^{+}$(APC), $\mathrm{CD} 8 \beta^{+}$(FITC), and CD8 $\alpha^{+}$(PE) antibodies. Each sample collected $1 \times 10^{5}$ cells for flow cytometric analysis. The circle or fame indicated the gated target cell population labelled by various antibodies. And the red arrow indicated that each $\mathrm{CD} 8 \alpha^{+} \mathrm{T}$ cell population was further subdivided to CD $8 \alpha \alpha$ and $\mathrm{CD} 8 \alpha \beta$ phenotype.

\section{Discussion}

As an avian retrovirus, ALV-J can integrate into the host genome, causing tumor disease and inducing immunological tolerance mainly via the vertical transmission, which makes it very hard to eliminate and control. So far, ALV-J eradication has been the main strategy used to control it via eliminating positively infected chickens. Although it works, it does not mean that it has been defeated, since little is known about the host's immune response to the virus. Previously, our research team and other researchers performed numerous studies on the innate immune response to ALV-J infection, as well as the interaction between ALV-J and macrophage, monocyte, and dendritic cells $[12,13,17,26,27]$. However, studies on the cellular immune response to ALV-J infection and the interaction between 
ALV-J and T cell are very few. More importantly, no study has been conducted about the systematical identification of host immune key factors against viral infection.

In this study, we established an infection model in which four-week-old SPF chickens were infected with ALV-J, after which the optimal host immune response was detected. We found that the $\mathrm{CD}^{+} \mathrm{T}$ cell response in PBL was obviously triggered after ALV-J infection at as early as 7 DPI $(p<0.05)$ and 21 DPI $(p<0.01)$ (Figure 2A). The production of the ALV-J antibody started from 21 DPI, which then slightly increased (Figure 1C). These results imply that ALV-J infection induced a cellular immune response, and the humoral immunity differed greatly in the time scale of the induction level, with a clearly detectable hierarchy. The ALV-J viremia was significantly decreased before antibody production at 14 DPI (Figure 1B,C). More interestingly, ALV-J viremia of four chickens could even be eliminated without antibody production (Figure 1C,D, Table S1), which suggests that the $\mathrm{CD} 8^{+} \mathrm{T}$ cell response was the potential key factor to defending against ALV-J infection. The thymus could provide the naïve $\mathrm{T}$ cell to the peripheral lymphatic organs via blood circulation [24]. Therefore, the obvious up-regulated percentage of $\mathrm{CD}^{+} \mathrm{T}$ cells in the thymus at $14 \mathrm{DPI}(p<0.01)$ may indicate the continuous output of $\mathrm{CD}^{+} \mathrm{T}$ cells from the thymus to the PBL. Studies have shown that the lower ration of $\mathrm{CD} 4^{+} / \mathrm{CD}^{+}$ could induce immune suppression $[28,29]$. Here, we also found that the ration of $\mathrm{CD} 4^{+} / \mathrm{CD} 8^{+}$in the thymus at 14 DPI $(p<0.05)$ and the PBL at 21 DPI $(p<0.01)$ decreased after ALV-J infection, which implied that the virus may have exerted the immunosuppressive effect at this period.

Immune-related genes are important mediators and regulators of the host immune response against foreign antigens. For detecting the expression profile of immune-related genes in the PBL after ALV-J infection, we picked up four kinds of immune-related genes, including the cytotoxicity gene, Th2 cytokine, innate immune gene, and inflammatory cytokines and chemokines to analyze them according to the published papers, as shown in the reference of Table 1. Previously, the transcriptional expression level of cytotoxicity-associated genes were investigated in chickens infected with Marek's Disease Virus (MDV), the infectious bursal disease virus (IBDV), and avian infectious bronchitis virus (IBV) [23,30-32]. In this study, we found that granzyme K, NK lysin, and IFN- $\gamma$ were up-regulated $(p<0.05)$, which may be associated with the stage of activation of cytotoxic T lymphocytes (CTLs) in ALV-J infected PBL. Besides, the Th2 cytokines, including IL-13 and IL-4, were increased $(p<0.05)$, which may have been involved in assisting the humoral immune response [18,33]. ISGs have been found to be critical for controlling virus infections [34]. Here, we found that ALV-J infection triggered the up-regulated expression of two chicken antiviral ISGs, Mx1 [35] and IFIT5 [36]. Chemokine could regulate the circulation of immune cells and their recruitment to sites of infection. The mRNA expression of CXCLi1 and CXCLi2 can be induced in lymphocytes, heterophils, and oviduct epithelial cells $[37,38]$. We found that CXCLi1 at 7 DPI was obviously increased in ALV-J infected PBL $(p<0.05)$, which may be related to the migration of the $\mathrm{CD} 8^{+} \mathrm{T}$ cell from the thymus to PBL.

The above results indicated that the $\mathrm{CD}^{+} \mathrm{T}$ cell response, accompanied by the cytotoxicityassociated genes, including granzyme K, NK lysin, and IFN- $\gamma$, may have been the key factor to defending against ALV-J infection in PBL. Given these findings, we further identified the phenotype of the $\mathrm{CD}^{+} \mathrm{T}$ cell response after ALV-J infection. The experiments presented in the current study showed that a CD8 hight population appeared in the ALV-J infected chicken from 21 DPI compared with uninfected chicken (Figure 6). It is well-known that CD8 is expressed either as an $\alpha \alpha$-homodimer or $\alpha \beta$-heterodimer, and CD8 $\alpha \beta$ is expressed in normal cytotoxic T cells [25]. In this study, we found that the majority of the $\mathrm{CD} 8{ }^{\text {high }+}$ population were of the $\mathrm{CD} 8 \alpha \beta$ phenotype (Figure $7 \mathrm{~B}, \mathrm{C}$ and Figure 8 ). Accordingly, the $\mathrm{CD} 8{ }^{\text {hight }}$ population with a $\mathrm{CD} 8 \alpha \beta$ phenotype seemed to play a vital role in virus clearance. The specific effect response mechanism of this CD8 hight population needs to be further verified. For example, identifying immunodominant viral antigens or epitopes eliciting this effective immune response would guide the development and design of effective ALV-J vaccines.

In summary, for the first time, this study systematically explored host immune key factors against viral infection in the PBL of ALV-J infected SPF chickens. We found that the CD8 hight $\mathrm{T}$ cell response 
of the $\mathrm{CD} 8 \alpha \beta$ phenotype may produce granzyme K, NK lysin, or IFN- $\gamma$ for clearing the virus. These findings provide novel insights and directions for developing effective ALV-J vaccines.

Supplementary Materials: The following are available online at http:/www.mdpi.com/1999-4915/12/1/114/s1.

Author Contributions: M.D. participated in the design of the study, performed the experiments, collected and analyzed data, and drafted the manuscript. S.L. and K.S. participated in the animal experiment and flow cytometer. J.L. and H.S. participated in the qPCR. M.L. participated in the design, coordination of the study and revising manuscript. All authors have read and agreed to the published version of the manuscript.

Funding: This research was funded by the National Natural Science Foundation grant (31802174) and China Postdoctoral Science Foundation Grants (2019T120735 and 2018M630956).

Conflicts of Interest: The authors declare no conflict of interest. The funders had no role in the design of the study; in the collection, analyses, or interpretation of data; in the writing of the manuscript, or in the decision to publish the results.

\section{References}

1. Payne, L.N.; Nair, V. The long view: 40 years of avian leukosis research. Avian Pathol. 2012, 41, 11-19. [CrossRef] [PubMed]

2. Dai, M.M.; Feng, M.; Xie, T.T.; Li, Y.F.; Zhang, X.Q. Fluctuations in luteinizing hormone, follicle stimulating hormone, and progesterone might affect the disappearance of avian leukosis virus subgroup J viremia in chickens with intermittent viremia. Poult. Sci. 2019, 98, 3533-3538. [CrossRef] [PubMed]

3. Zhang, L.M.; Cai, D.J.; Zhao, X.N.; Cheng, Z.Q.; Guo, H.J.; Qi, C.H.; Liu, J.Z.; Xu, R.X.; Zhao, P.; Cui, Z.Z. Liposomes containing recombinant gp85 protein vaccine against ALV-J in chickens. Vaccine 2014, 32, 2452-2456. [CrossRef] [PubMed]

4. Dou, W.W.; Li, H.M.; Cheng, Z.Q.; Zhao, P.; Liu, J.X.; Cui, Z.Z.; Liu, H.G.; Jing, W.F.; Guo, H.J. Maternal antibody induced by recombinant gp85 protein vaccine adjuvanted with CPG-ODN protects against ALV-J early infection in chickens. Vaccine 2013, 31, 6144-6149. [CrossRef]

5. Xu, Q.Q.; Ma, X.J.; Wang, F.K.; Li, H.M.; Zhao, X.M. Evaluation of a multi-epitope subunit vaccine against avian leukosis virus subgroup J in chickens. Virus Res. 2015, 210, 62-68. [CrossRef]

6. Xu, Q.Q.; Cui, N.; Ma, X.J.; Wang, F.K.; Li, H.M.; Shen, Z.Q.; Zhao, X.M. Evaluation of a chimeric multi-epitope-based DNA vaccine against subgroup J avian leukosis virus in chickens. Vaccine 2016, 34, 3751-3756. [CrossRef]

7. Dai, M.M.; Feng, M.; Ye, Y.; Wu, X.C.; Liu, D.; Liao, M.; Cao, W.S. Exogenous avian leukosis virus-induced activation of the ERK/AP1 pathway is required for virus replication and correlates with virus-induced tumorigenesis. Sci. Rep. 2016, 6, 19226. [CrossRef]

8. Li, Y.H.; Liu, X.M.; Liu, H.X.; Xu, C.G.; Liao, Y.L.; Wu, X.C.; Cao, W.S.; Liao, M. Isolation, identification, and phylogenetic analysis of two avian leukosis virus subgroup J strains associated with hemangioma and myeloid leukosis. Vet. Microbiol. 2013, 166, 356-364. [CrossRef]

9. Zhang, H.N.; Lai, H.Z.; Qi, Y.; Zhang, X.T.; Ning, Z.Y.; Luo, K.J.; Xin, C.A.; Cao, W.S.; Liao, M. An ALV-J isolate is responsible for spontaneous haemangiomas in layer chickens in China. Avian Pathol. 2011, 40, 261-267. [CrossRef]

10. Wang, F.; Wang, X.W.; Chen, H.B.; Liu, J.Z.; Cheng, Z.Q. The critical time of avian leukosis virus subgroup J-mediated immunosuppression during early stage infection in specific pathogen-free chickens. J. Vet. Sci. 2011, 12, 235-241. [CrossRef]

11. Qualtiere, L.F.; Meyers, P. A reexamination of humoral tolerance in chickens congenitally infected with an avian leukosis virus. J. Immunol. 1979, 122, 825-829. [PubMed]

12. Feng, M.; Dai, M.M.; Xie, T.T.; Li, Z.H.; Shi, M.Q.; Zhang, X.Q. Innate Immune Responses in ALV-J Infected Chicks and Chickens with Hemangioma In Vivo. Front. Microbiol. 2016, 7, 786. [CrossRef] [PubMed]

13. Feng, M.; Zhang, X.Q. Immunity to Avian Leukosis Virus: Where Are We Now and What Should We Do? Front. Immunol. 2016, 7, 624. [CrossRef] [PubMed]

14. Dai, M.M.; Xu, C.G.; Chen, W.S.; Liao, M. Progress on chicken T cell immunity to viruses. Cell. Mol. Life Sci. 2019, 76, 2779-2788. [CrossRef] [PubMed]

15. Livak, K.J.; Schmittgen, T.D. Analysis of relative gene expression data using real-time quantitative PCR and the 2(-Delta Delta C(T)) Method. Methods 2001, 25, 402-408. [CrossRef] [PubMed] 
16. Dai, M.M.; Wu, S.Y.; Feng, M.; Feng, S.X.; Sun, C.; Bai, D.Y.; Gu, M.Z.; Liao, M.; Cao, W.S. Recombinant chicken interferon-alpha inhibits the replication of exogenous avian leukosis virus (ALV) in DF-1 cells. Mol. Immunol. 2016, 76, 62-69. [CrossRef]

17. Liu, D.; Qiu, Q.Q.; Zhang, X.; Dai, M.M.; Qin, J.R.; Hao, J.J.; Liao, M.; Cao, W.S. Infection of chicken bone marrow mononuclear cells with subgroup J avian leukosis virus inhibits dendritic cell differentiation and alters cytokine expression. Infect. Genet. Evol. 2016, 44, 130-136. [CrossRef]

18. Liu, H.W.; Zhang, M.F.; Han, H.T.; Yuan, J.H.; Li, Z.D. Comparison of the expression of cytokine genes in the bursal tissues of the chickens following challenge with infectious bursal disease viruses of varying virulence. Virol. J. 2010, 7, 364. [CrossRef]

19. Lee, C.C.; Kim, B.S.; Wu, C.C.; Lin, T.L. Bursal transcriptome of chickens protected by DNA vaccination versus those challenged with infectious bursal disease virus. Arch. Virol. 2015, 160, 69-80. [CrossRef]

20. Humphries, F.; Yang, S.; Wang, B.; Moynagh, P.N. RIP kinases: Key decision makers in cell death and innate immunity. Cell Death Differ. 2015, 22, 225-236. [CrossRef]

21. Qi, X.F.; Liu, C.H.; Li, R.Q.; Zhang, H.Z.; Xu, X.G.; Wang, J.Y. Modulation of the innate immune-related genes expression in H9N2 avian influenza virus-infected chicken macrophage-like cells (HD11) in response to Escherichia coli LPS stimulation. Res. Vet. Sci. 2017, 111, 36-42. [CrossRef] [PubMed]

22. Liu, A.L.; Li, Y.F.; Qi, W.; Ma, X.L.; Yu, K.X.; Huang, B.; Liao, M.; Li, F.; Pan, J.; Song, M.X. Comparative analysis of selected innate immune-related genes following infection of immortal DF-1 cells with highly pathogenic (H5N1) and low pathogenic (H9N2) avian influenza viruses. Virus Genes 2015, 50, 189-199. [CrossRef] [PubMed]

23. Sarson, A.J.; Abdul-Careem, M.F.; Read, L.R.; Brisbin, J.T.; Sharif, S. Expression of Cytotoxicity-Associated Genes in Marek's Disease Virus-Infected Chickens. Viral Immunol. 2008, 21, 267-272. [CrossRef] [PubMed]

24. Dunon, D.; Allioli, N.; Vainio, O.; Ody, C.; Imhof, B.A. Quantification of T-cell progenitors during ontogeny: Thymus colonization depends on blood delivery of progenitors. Blood 1999, 93, 2234-2243. [CrossRef] [PubMed]

25. Luhtala, M. Chicken CD4, CD8alphabeta, and CD8alphaalpha T cell co-receptor molecules. Poult. Sci. 1998, 77, 1858-1873. [CrossRef]

26. Dai, M.M.; Feng, M.; Xie, T.T.; Zhang, X.Q. Long non-coding RNA and MicroRNA profiling provides comprehensive insight into non-coding RNA involved host immune responses in ALV-J-infected chicken primary macrophage. Dev. Comp. Immunol. 2019, 100, 103414. [CrossRef]

27. Dai, M.M.; Feng, M.; Xie, T.T.; Li, Y.F.; Ruan, Z.H.; Shi, M.Q.; Liao, M.; Zhang, X.Q. ALV-J infection induces chicken monocyte death accompanied with the production of IL-1beta and IL-18. Oncotarget 2017, 8, 99889-99900. [CrossRef]

28. Fu, L.S.; Wang, X.Y.; Zhai, J.; Qi, W.; Jing, L.; Ge, Y.Y.; Gao, X.L.; Liu, C.N.; Lv, X.P.; Zheng, S.M. Changes in apoptosis, proliferation and $\mathrm{T}$ lymphocyte subtype on thymic cells of SPF chickens infected with reticuloendotheliosis virus. Mol. Immunol. 2019, 111, 87-94. [CrossRef]

29. Xue, M.; Shi, X.M.; Zhao, Y.; Cui, H.Y.; Hu, S.L.; Cui, X.L.; Wang, Y.F. Effects of Reticuloendotheliosis Virus Infection on Cytokine Production in SPF Chickens. PLoS ONE 2013, 8, e83918. [CrossRef]

30. Wang, X.Q.; Rosa, A.J.M.; Oliverira, H.N.; Rosa, G.J.M.; Guo, X.S.; Travnicek, M.; Girshick, T. Transcriptome of Local Innate and Adaptive Immunity during Early Phase of Infectious Bronchitis Viral Infection. Viral Immunol. 2006, 19, 768-774. [CrossRef]

31. Rauf, A.; Khatri, M.; Murgia, M.V.; Saif, Y.M. Expression of perforin-granzyme pathway genes in the bursa of infectious bursal disease virus-infected chickens. Dev. Comp. Immunol. 2011, 35, 620-627. [CrossRef] [PubMed]

32. Rauf, A.; Khatri, M.; Murgia, M.V.; Saif, Y.M. Fas/FasL and perforin-granzyme pathways mediated T cell cytotoxic responses in infectious bursal disease virus infected chickens. Results Immunol. 2012, 2, 112-119. [CrossRef] [PubMed]

33. Avery, S.; Rothwell, L.; Degen, W.D.; Schijns, V.E.; Young, J.; Kaufman, J.; Kaiser, P. Characterization of the first nonmammalian T2 cytokine gene cluster: The cluster contains functional single-copy genes for IL-3, IL-4, IL-13, and GM-CSF, a gene for IL-5 that appears to be a pseudogene, and a gene encoding another cytokinelike transcript, KK34. J. Interferon Cytokine Res. 2004, 24, 600-610. [PubMed]

34. Schoggins, J.W. Interferon-stimulated genes: Roles in viral pathogenesis. Curr. Opin. Virol. 2014, 6, 40-46. [CrossRef] [PubMed] 
35. Sasaki, K.; Yoneda, A.; Ninomiya, A.; Kawahara, M.; Watanabe, T. Both antiviral activity and intracellular localization of chicken Mx protein depend on a polymorphism at amino acid position 631. Biochem. Biophys. Res. Commun. 2013, 430, 161-166. [CrossRef] [PubMed]

36. Santhakumar, D.; Rohaim, M.A.M.S.; Hussein, H.A.; Hawes, P.; Ferreira, H.L.; Behboudi, S.; Iqbal, M.; Nair, V.; Arns, C.W.; Munir, M. Chicken Interferon-induced Protein with Tetratricopeptide Repeats 5 Antagonizes Replication of RNA Viruses. Sci. Rep. 2018, 8, 6794. [CrossRef] [PubMed]

37. Shini, S.; Shini, A.; Huff, G. Effects of chronic and repeated corticosterone administration in rearing chickens on physiology, the onset of lay and egg production of hens. Physiol. Behav. 2009, 98, 73-77. [CrossRef]

38. Chappell, L.; Kaiser, P.; Barrow, P.; Jones, M.A.; Johnston, C.; Wigley, P. The immunobiology of avian systemic salmonellosis. Vet. Immunol. Immunopathol. 2009, 128, 53-59. [CrossRef]

(C) 2020 by the authors. Licensee MDPI, Basel, Switzerland. This article is an open access article distributed under the terms and conditions of the Creative Commons Attribution (CC BY) license (http://creativecommons.org/licenses/by/4.0/). 